\title{
FREEDOM OF CONSCIENCE AND RELIGION IN THE FAMILY AND CRIMINAL LAW OF THE SLOVAK REPUBLIC
}

\author{
Vojtech VLADÁR ${ }^{1}$
}

Freedom of conscience and religion is one of the most important areas of legal protection, reflecting a high level of both culture and democratization for contemporary states. This is especially significant for the countries of the former Eastern Bloc, which experienced decades of totalitarianism under socialist regimes. The protection of conscience and religious rights is always reflected in several sources of law, commencing with the constitution, and this is also the case of the Slovak Republic. The constitutional rights in this area were reflected also in other branches of law, such as family law, covering the private integrity of every individual, and criminal law, which deals with the most serious violations of legal norms. This study discusses the elements of state religious law contained in the family and criminal law of the Slovak Republic, starting with the nation's older legal regulations.

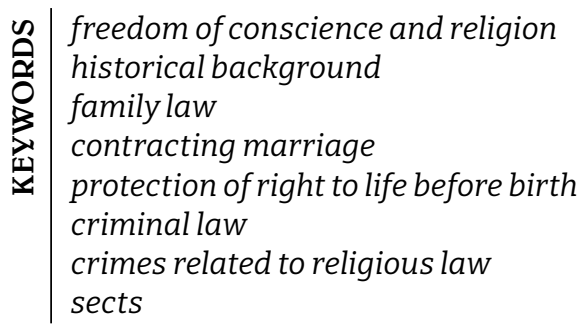

\section{Introduction}

Churches and religious societies (especially the Catholic Church) played one of the most significant roles in the history of Slovakia, especially during times of national revival, when several of those who asserted Slovakian national rights were Catholic or Evangelical priests. This history is reflected in the large number of Slovakians who avow

1 | Professor, Department of Roman Law, Canon, and Church Law, Faculty of Law, Comenius University in Bratislava, Slovakia, vojtech.vladar@flaw.uniba.sk. 
religiosity or membership in a church or religious society. ${ }^{2}$ Most Slovakians consider a church or religious society as an integral part of their social structure and, at least formally, as an important factor in their identity. It was difficult for them to accept the rise to power of the socialist regime, which regarded churches and religious societies as an ideological enemy, restricted their activities and social influence, placed them under political and economic surveillance, and led to their international isolation. ${ }^{3}$ The current status of churches and religious societies in the Slovak Republic was made possible by the events of November 1989, which afforded them unprecedented possibilities and allowed them to continue their traditional role in the formation of the nation. The Slovakian state now fully accepts the churches' social status and cooperates with them according to the principles of partnership collaboration. ${ }^{4}$ The status of churches and religious societies in the Slovak Republic is not only fully comparable to that of churches and religious societies in other democratic states but may even be somewhat better. In accordance with contemporary standards, religious features are reflected in several elements of Slovakia's state, family, and criminal law not omitting. Amid the social-political changes of 1989, Slovakia reformed its family law. The principal change was recognizing marriages contracted before clergy and making them equal to so-called 'civil marriages'. Moreover, Slovakia's Criminal Code novelized or added several subject matters that directly or indirectly protect the individual and collective religious freedom.

\section{Family Law}

As in the rest of Europe, family law was regulated according to the rules of canon law (the law of the Catholic Church) for centuries in the territory that today constitutes Slovakia. This is demonstrated by the sources compiled in the $9^{\text {th }}$ century by Byzantine missionaries Constantine ( $₫$ 869) and Methodius ( $₫ 885)$, who not only spread and strengthened the Catholic faith in Great Moravia but were also one of the first pioneers in matters of law. Constantine's compilation entitled 'Zákon súdnyj l'judem' (Law for Judging Laymen) set forth rules for family and marriage law, alongside rules for property, criminal, and procedural law. ${ }^{5}$ In a country full of pagan customs, including polygamy, fostering the purity of matrimonial monogamy was an important task for missionaries serving in Great Moravia. These social relations were regulated in a similar way in Methodius' Nomocanon, which also contained rules for family and marriage law, including a criminal sanction against abortion. From the times of High Middle Ages at latest, the Catholic courts dominated in the area of marriage law and this status persisted until the Protestant Reformation, when Protestants managed to acquire various civil liberties in several countries, including those related to matters of marriage. However, the territory that now comprises Slovakia continued to be

2 | According to the last population and housing census (2011), 76\% of the population indicated that they followed a religion (https://census2011.statistics.sk/tabulky.html). The author could not use the results of the 2021 census of population and housing, as it was in progress during the writing of this article.

3 | Cf. Grešková, 2008, p. 10.

4 | Cf. Čikeš, 2010, pp. 8, 39.

5 | Cf. Valeš, 2008, p. 65. 
governed by the authority of Catholic courts in this area until the religious reforms of Holy Roman Emperor Joseph II (1765/1780-1790). In 1781, the Patent of Toleration (the provisions of which extended even to Hungary) removed the matrimonial affairs of Protestants from the authority of the Catholic Church. ${ }^{6}$ This trend continued into 1868, when the Hungarian Parliament confined the competence of Catholic courts to cases involving Catholics; the child of a mixed marriage had to follow the religion professed by the parent of the child's gender. ${ }^{7}$ Another intervention in this area was the 1894 mandating of civil marriage and its state registration (with effect from October $1,1895)$, after which the judgements of Church tribunals in marriage cases were no longer accepted by state bodies. ${ }^{8}$

The civil status of church marriage was recognized by the First Czechoslovak Republic (1918-1938), despite the frequently hostile attitude to Catholicism taken by Czech state representatives, though the republic considered married couples divorceable. ${ }^{9}$ This allowed an alternative form of marriage contract. In Hungary, civil marriage had been obligatory, and the republic's law was favourable to the Catholic doctrine and canon law. After the socialist regime took power in 1948, its ideas were transplanted into family law. Law No. 265/1949 Sb. made civil marriage obligatory. This obligatory civil marriage contract had to precede marriage before the clergy of a recognized church or religious society. Any clergy that violated this regulation, even through negligence, faced punishment under the provisions of the Criminal Code of 1950, including the possibility of imprisonment for up to one year. ${ }^{10}$ Marriage ceremonies could take place only before the local national committee. A related rule, Law No. 268/1949 Sb., removed from churches and religious societies authority over records of births, marriages, and deaths and transferred it to the state. ${ }^{11}$ This trend continued in the Law on Family (1963), which similarly prohibited religious wedding ceremonies before a civil marriage had been

6 | Cf. Kumor, Dlugoš, 2003, p. 112-113. Until then, Protestants could, following the resolutions of the Congress of Sopron of 1681, elect their own superintendents, but their baptisms were henceforth subjected to the supervision of Catholics, and their marriage cases were supervised by Catholic tribunals. Mixed marriages could be contracted only before Catholic clergy, and children from these marriages had to be raised in the Catholic faith; cf. Tretera, 2002, pp. 20, 25. On the other hand, it is necessary to admit that the authority of Catholic courts over marriage matters had been restricted from the time of the Empress Maria Theresa (1740/1765-1780). Her son Joseph II indeed retained the Church form of contracting marriage, but marriage litigation was removed from the competence of Church courts and assigned to state courts. The same attitude was seen in the Austrian 'Allgemeines bürgerliches Gesetzbuch' (ABGB) of 1811, which received from canon law several institutions and regulations, such as marriage impediments and separation from table and bed (separatio a mensa et thoro), which were eventually extended to non-Catholics; cf. Malý, 2001, p. 230.

7 | The Austrian Constitution of 1867, directly opposing the provisions of the Concordat of 1855, accepted the exclusive competence of state courts in marriage cases and declared that children from mixed marriages should follow the confession of the parent with whom they shared a gender. The concordat recognized the sovereignty of the Catholic Church over the marriages of Catholics; cf. Samsour, 1907, p. 1092.

8 | Cf. Kumor, 2003, p. 291.

9 | Cf. zákon č. 320/1919 Sb. z. a n., vykonávacie nariadenie č. 362/1919 Sb. z. a n. and zákon č. 113/1924 Sb.z.an.

10 | Cf. § 207 zákona č. 86/1950 Sb., Trestný zákon.

11 | Cf. Valeš, 2008, p. 146. 
contracted. ${ }^{12}$ State interference in family matters deepened during the so-called 'normalization' period (1968-1989), when liturgical ceremonies were frequently replaced by secular substitutes. ${ }^{13}$

After the fall of the socialist regime, family law, including that governing marriage contracts, was subsumed under the traditional scope of res mixtae ('mixed matters', affecting both churches/religious societies and the state) following international standards. ${ }^{14}$ This is not surprising, since the communist-era Law on Family accepted the family as the fundamental cell of society; this was kept in the new law. ${ }^{15}$ After the fall of the socialist regime, the Law on Family was amended by No. 234/1992 Sb., which changed not only the Law on Family but also Law No. 97/1963 Sb. on International Private and Procedural Law. This law restored marriage contract alternatives to Czechoslovakia and gave civil effect to marriages contracted before the clergy of registered churches and religious societies. ${ }^{16}$ Religious and secular forms of marriage contract were thereby equalized, and it was no longer necessary to have a civil ceremony after being married in a religious ceremony. ${ }^{17}$ According to $\S 3$ of this law, marriage was contracted through the consenting proclamation of a man and woman before a competent state body or registered church or religious society..$^{18}$ This amendatory act allowed the contracting of a church marriage at a church or other appropriate place specified by the rules of the given church or religious society. ${ }^{19}$ The application to contract a marriage had to made in writing on specified stationery at a registry office or an office specified by the given church or religious society. A report on the contracted church marriage had to be sent to the registry office by a competent body of the church or religious society within three days. ${ }^{20}$ This office then recorded the contracted marriage into the book of marriages and issued a certificate of marriage to the spouses. ${ }^{21}$

12 | The clergymen were threatened with imprisonment for up to one year in case of violation; cf. § 211 zákona č. 140/1961 Sb., Trestný zákon. The law prohibited the church form of contracting marriage even in a foreign state that recognized it; cf. § 20 zákona č. 97/1963 Sb. o mezinárodnom práve súkromnom a procesnom. Although the original conception of this family law assumed a parental duty to raise children in a so-called 'scientific' world-view (i.e. atheism), these endeavours were not successful thanks to the opposition of the religious representatives. The law proclaimed, however, that the morality of the socialist society had to be the basis of all relations in a family; cf. úvod and $\S$ 31 zákona č. 94/1963 Sb. o rodine; see also Tretera, 2002, p. 12.

13 | Cf. Madleňáková, 2004, p. 63.

14 | Cf. Čeplíková, 2011, p. 137.

15 | Cf. čl. 2 zákona č. 36/2005 Z. z. o rodine.

16 | Cf. Hrdina, 1996, pp. 417-424.

17 | Cf. Fischerová, 1992, p. 25.

18 | The registration was regulated by Law No. 308/1991 Zb. on Freedom of Religious Belief and the Status of Churches and Religious Societies; cf. §§ 10-21 zákona č. 308/1991Zb. o slobode náboženskej viery a postavení cirkví a náboženských spoločností.

19 | Of course, all the obligatory legal conditions had to be met, such as legal capacity, age as provided by law (18 years or, exceptionally, 16 years), single status, proven dissolution of preceding marriage, and absence of blood relations of specified degree. Those willing to enter a marriage had to submit the proper papers and declare their lack of knowledge of any circumstances that would preclude them from contracting marriage and knowledge of their health state; cf. § 4b zákona č. 234/1992 Sb.

20 | Cf. § 27, ods. 6 zákona č. 154/1994 Z. z. o matrikách.

21 | See also Čeplíková, 2011, p. 138. 
This status was confirmed by the still-valid Law No. 36/2005 Z. z. on Family, according to which the state broadly protects marriage as a unique bond between man and woman. ${ }^{22}$ This law also considers that a marriage is contracted through the consenting proclamation of a man and woman before the registry office established in the district of residence of one of the persons entering the marriage (in a so-called 'civil marriage' ${ }^{23}$ or before the body of a registered church or religious society (in a so-called 'church marriage'). ${ }^{24}$ A marriage is thus contracted by a couple willing to enter the marriage before someone performing the duties of the clergy of a registered church or religious society. ${ }^{25}$ The clergy's competence in assisting at the contracting of a marriage has an official and public-law character, since the public power to perform this act was entrusted to them by the state. A marriage is not valid if such a proclamation is made before a non-registered church or religious society or before someone who is not authorized to perform the duties of the clergy of a registered church or religious society. ${ }^{26} \mathrm{~A}$ church marriage is contracted at a church or other appropriate place specified by the rules of the given church or religious society for religious ceremonies and acts. The equality of status and effects between marriages contracted before the body of a registered church or religious society and civil marriages was later confirmed by the 2001 Basic Treaty between the Slovak Republic and the Holy See, as well as the 2002 Agreement between the Slovak Republic and registered churches and religious societies. ${ }^{27}$

Of course, church marriages have to meet all obligatory conditions specified by law. Those seeking to enter a marriage file the required papers such as their birth certificate,

22 | Cf. čl. 1 zákona č. 36/2005 Z. z. o rodine and čl. 41, ods. 1 ústavného zákona č. 460/1992 Zb., Ústava Slovenskej republiky. A similar attitude is seen in the regulation of marriage contracts of Slovak Republic citizens living abroad. In 1992, a change with retrospective force and retroactive legal effects was put into practice whereby church marriages contracted by Czechoslovak citizens abroad from January 1, 1950 (day of establishment of obligatory civil marriage) to June 30, 1992 (the day facultative marriage was introduced), valid according to the law of a given state, were considered to be valid even by the law of the Slovak Republic (from July 1, 1992). Until then, civil marriage was required even if a marriage had been contracted in a state recognizing the church marriages. The form of marriage contract has since then been regulated by the law of the place where the marriage was contracted. This means that citizens of the Slovak Republic have to respect and observe the specified form of marriage contract in a given state; cf. čl. § 20 zákona č. 97/1963 Zb. o medzinárodnom práve súkromnom a procesnom and § 112 zákona č. 36/2005 Z. z. o rodine.

23 | Cf. § 4 zákona č. 36/2005 Z. z. o rodine.

24 | Cf. § 5 zákona č. 36/2005 Z. z. o rodine.

25 I I suppose it is more appropriate to use the canonistic term nupturiens, meaning 'person contracting marriage'. Even this term could be improved by the word nupturus, meaning 'willing to enter the marriage', since its origin depends on the objective circumstances by which marriage comes into existence or not. However, the Law on Family, as well as the Law on Register Offices No. 154/1994 Z. z. and its Executing Edict No. 302/1994 Z. z. use the terms 'fiancé/fiancée' or 'fiancées', even though this institution is not specified in these sources. All the same, from the canon law point of view, betrothal has no impact on the origin of marriage and is thus not obligatory before the marriage; cf. §§1-2, 4-8 and 105 zákona č. 36/2005 Z. z. o rodine; §§ 27 and 30 zákona č. 154/1994 Z. z. o matrikách and vyhláška č. 302/1994 Z. z. I had dealt with these matters with my colleague; cf. Laclavíková, Vladár, 2017, p. 215.

26 | Cf. § 17, písm. d) zákona č. 36/2005 Z. z. o rodine.

27 | Cf. čl.10, ods.1Základnej zmluvy medzi Slovenskou republikou a Svätou Stolicou vyhlásenej pod číslom 326/2001 Z. z. ako oznámenie Ministerstva zahraničných vecí and čl. 10, ods.1 Dohody medzi Slovenskou republikou a registrovanými cirkvami a náboženskými spoločnost́ami publikovanej pod č. 250/2002 Z. z. See also Čeplíková, 2011, p. 196. 
certificate of residence, certificate of citizenship, death certificate, or other document proving the termination of a prior marriage to the registry office. ${ }^{28}$ All necessary data are then sent to the locally competent church body. After the marriage is contracted, the assisting church or religious society must deliver a report on the contract to the competent registry office within three days. However, the marriage has legal effect as soon as it is contracted before the officiating clergy. Regarding the termination of marriage, state law accepts the wish to divorce as a valid reason for dissolution under the authority of the state court. The canon law-based decisions of competent Catholic Church authorities have no secular law effects. This situation is covered by the Basic Treaty between the Slovak Republic and the Holy See, according to which canon law decisions on the nullity or dissolution of marriage can be sent by the request of one of the spouses to the Slovak Republic, which will then act in accordance with state law. The state has not attempted to bring these procedures closer together through law. ${ }^{29}$ Majority of other registered churches and religious societies in Slovakia accept state competence in matrimonial matters and divorce cases. ${ }^{30}$

Regarding family law and freedom of conscience and religion, it is necessary to mention the protection of life before birth - namely, the issue of abortion. The prohibition against abortion was abrogated amid the overall $20^{\text {th }}$-century trend toward secularisation, which also affected Slovakia. This prohibition had stood for centuries, and was included not only in Hungarian law but also in the first socialist Criminal Code. Abortions had been permitted only when the life of the mother was threatened or when it was suspected that the foetus had a genetic disorder. Abortion was officially allowed in 1957, and the law became increasingly liberal afterward..$^{31}$ Nevertheless, only in 1986 did Slovakian law accept that parents' right to determine and regulate the number of their children is an inseparable element of modern civilization. The state retained this view after the fall of the socialist regime..$^{32}$ However, it has been pointed out often that allowing abortions is in direct conflict with Article 15, Section 1 of the Constitution of the Slovak Republic, which guarantees the protection of life before birth. ${ }^{33}$ In 2001, a group of representatives of the 'Krestanské demokratické hnutie' (Christian Democratic Movement) challenged the constitutionality of Slovakia's abortion law by arguing that it was immoderate in allowing for motiveless abortion. This argument was rejected by the Constitutional Court of the Slovak Republic in 2007. In its ruling, the court agreed with the findings of the European Court for Human Rights and declared that life was sufficiently protected under the law despite the fact that a woman could obtain a legal abortion up to the twelfth week of her pregnancy. Thus, Law No. 73/1986 Zb. is considered to be in accordance with the Constitution of the

28 | These papers must be submitted only if their information is not contained in the identity card; cf. §§ 27 and 28 zákona č. 154/1994 Z. z. o matrikách.

29 | Cf. čl. 10, ods. 2 Základnej zmluvy medzi Slovenskou republikou a Svätou Stolicou vyhlásenej pod číslom 326/2001Z. z. ako oznámenie Ministerstva zahraničných vecí.

30 | The treaty requests that the church dissolution of marriage conforms to Slovak law; cf. čl.10, ods. 2 Dohody medzi Slovenskou republikou a registrovanými cirkvami a náboženskými spoločnost́ami publikovanej pod č. 250/2002 Z. z. Elements of the Law on Family may be seen in Article 4 and $\S$ 30. Section 1 passed in accordance with the international duties of the Slovak Republic, according to which parents have the right to raise their children in ways consistent with their religious or philosophical convictions; cf. čl. 4 and § 30, ods. 1 zákona č. 36/2005 Z. z. o rodine.

31 | Cf. § 1 zákona č. 68/1957 Zb. o umelom prerušení tehotenstva.

32 | Cf. §1 zákona č. 73/1986 Zb. o umelom prerušení tehotenstva.

33 | Cf. čl.15, ods. 1 ústavného zákona č. 460/1992 Zb., Ústava Slovenskej republiky. 
Slovak Republic. ${ }^{34}$ This matter came up in the National Council of the Slovak Republic in 2019, when several proposals were put forward to make the law more restrictive. These initiatives were also not successful..$^{35}$

\section{Criminal Law}

Canon law was also reflected in the criminal law for centuries. For example, Great Moravia (after the fashion of the Frankish Empire) before the arrival of the Byzantine mission enforced a public law conception of crime whereby it was perceived as not only a violation of secular law and a menace to society but also as an offence against God. ${ }^{36}$ Thus, every criminal law violation was met not only by a secular punishment but also by Church sanction in the form of public penance (epitímia). Missionaries ensured that established secular penalties were softened and often replaced by Church sanctions ${ }^{37}$ The sanctions of the 'Zákon súdnyj ljudem' were more severe than Byzantine models; however, most of its criminal sanctions containing capital and mutilating punishments were replaced by Church penance. Criminal law provisions included the Nomocanon and set out penance sanctions for murder, abortion, theft, simony, and nepotism. ${ }^{38}$ A similar attitude was shown by the first Hungarian king, Stephen I (997/1000-1038), who published his own legal code after the fashion of Frankish law, which was markedly affected by the Christian spirit. This was evident in its criminal law provisions, which regarded crime not only as a violation of secular law but as a sin. Church sanctions were often added to secular punishments. Under King Stephen I, the public law conception of crime was reasserted in Hungary, analogous to the Frankish Empire of the ninth century. Corporal punishments were commonly replaced by Church sanctions in the form of public penance..$^{39}$

34 | Cf. http://www.concourt.sk/sk/Tlacove_spravy/2007/TS_20071204-1.pdf.

35 | Cf. https://spravy.pravda.sk/domace/clanok/535067-parlament-neschvalil-navrh-sns-nastazenie-pristupu-k-interrupciam/.

36 | Public penance was imposed by Church courts from the $2^{\text {nd }}$ century; cf. $\Delta$ เ $\delta a \times \grave{\eta} 15,3$. This institution was applied for offences against faith, murder, fornication, and other serious delinquencies considered to be crimes under Church law. Public penance also afforded public sinners conciliation with the Church and readmission to Church society (communio). The believer had to first confess his or her error before the whole community and repent for a sufficient length of time, fasting and praying, sometimes for life, encouraged by the prayers of the community to reconcile with God; cf. Dolinský, 1996, p. 79. Its rigidity depended not only on the gravity of the delinquency, but also on the status of the member of the Church community (clergymen were punished more rigidly). Being received back into the community of believers required completing the penance; the only exception was made for the seriously ill; cf. Markschies, 2005, p. 172.

37 I Of course, all the rules were submitted after the Byzantine fashion for the sanctioning to the Great-Moravian sovereign; cf. Pokorný, 1987, p. 169. This may be illustrated by their translation of the well-known Penitential of Merseburg, made necessary because their disciples did not read Latin. This was despite the prohibition against translating the penitentials into the vernacular to prevent them from getting into the hands of laymen; cf. Responsa Nicolai ad consulta Bulgarorum 75. This was not a verbatim translation, since the translator adapted the content and the penalties to the needs of Great Moravia, and even used analogical Eastern rules; cf. Kizlink, 1969, p. 453n.

38 | Cf. Vašica, 1996, p. 74.

39 | Cf. Kumor, 2001, pp. 111,152. 
As in family law, Church competences were restrained in the area of criminal law during the Enlightenment. For example, Empress Maria Theresa restricted the court autonomy of the Catholic Church, even in criminal cases involving clergymen; this was later confirmed by legislation under Emperor Joseph II. ${ }^{40}$ Privilegium fori, according to which criminal cases involving clergymen were restricted to Church courts, was definitively abrogated in the second half of the $19^{\text {th }}$ century, during the so-called 'Kulturkampf' (1871-1886), which influenced both Hungary and Slovakia. ${ }^{41}$ The Kulturkampf may be described as an ideological controversy regarding the cultural, spiritual, political, and religious relations between the Catholic Church and the state. Hungarian criminal law remained in force in Slovakia after the formation of the First Czechoslovak Republic, including Article No. 5/1878 (Criminal Law on Crimes and Offences) and Law No. 40/1879 (Criminal Law on Offences). Thus, Slovakia was not touched by several of the Kulturkampf provisions unleashed by the Czech political representatives in Czech lands and Moravia, such as amendment No. 111/1919 Sb. z. a n., which supplemented the provision of $\S 303$ of the Austrian Criminal Law of 1852 (the so-called 'Kanzelparagraph' ['Pulpit Law']). This law was similar to the mentioned German one and provided from one to six years of imprisonment in Czech territories, but not in Slovakia or Carpathian Ruthenia. ${ }^{42}$ While these provisions were vulnerable to abuse, the socialist regime was paradoxically not content with them and thus abrogated them by enacting the derogatory clause of Law No. 231/1948 Sb. z. a n. for the Protection of People's Democratic Order.

Mentioned law allowed the state to prosecute all persons deemed disloyal to the regime and impose long-time imprisonment, property seizure, and the death penalty. In the two years of its existence (1948-1950), hundreds of citizens were convicted, including many believers, as well as high-level church officials. ${ }^{43}$ Several prosecutions were conducted against the representatives of religious orders and diocesan clergymen. The provisions of this law remained in effect even after its derogation, since they were assumed into the new Criminal Code of 1950, which criminalised the obstruction of supervision over churches and religious societies. ${ }^{44}$ This law also declared that criminal cases should be tried in such a way as to 'educate citizens to be vigilant towards enemies of working people and other disturbers of their communist enthusiasm and to the performance of

$40 \mid$ Cf. Tretera, 2002, p. 20.

41 | This term was used for the first time in 1873 by Professor Rudolf Ludwig Karl Virchow ( $† 1902)$ to describe the liberation of culture from the influence of the Church while discussing Prussia's so-called 'May laws' (1873); see also Weir, 2014.

42 I This sanction could be applied to the clergy of any confession who, during divine worship (e.g. teaching, procession, pilgrimage) or their preaching dealt with any matter of state or public life, criticized state laws, preferred any political party, or intervened in an election. The literature agrees that this law was then not used against churches and religious societies in Czechoslovakia; cf. Valeš, 2008, p. 128-129.

43 | Illicit religious activities consisted mostly of abusing spiritual offices or similar offences and incitement to violent or other hostile acts against groups of people based on their nationality, race, religious beliefs or irreligious state, or status as followers of the republic. This was typically used against clergy, for whom more severe penal sanctions were applied; the vague provisions allowed judicial arbitrariness, and crimes were alleged against the state, its external and internal security, and foreign relations; cf. $\S \S 26$ and 28 zákona č. 86/1950 Sb., Trestný zákon; cf. Tretera, 2002, p. 44. 44 | Cf. §§ 173-174 zákona č. 86/1950 Sb., Trestný zákon. None of the religious orders could dispose of their own novices, while violating this prohibition was considered a crime (that of obstructing the supervision over the churches and religious societies); cf. § 178 zákona č. 86/1950 Sb., Trestný zákon. See also Fiala, Hanuš, 2001, p. 103. 
civic duties' ${ }^{45}$ The strict measures against churches and religious societies also included Law No. 218/1949 Sb. on the Economic Assurance of Churches and Religious Societies, § 7 of which stipulated that clergyman may hold office only after obtaining consent from the Civil Office for Church Matters ${ }^{46}$ Clergymen were often punished for violating the law on obligatory civil marriage (i.e. for performing marriage ceremonies with persons who had not contracted a civil marriage). ${ }^{47}$ The state's totalitarian attitude was manifested in its creation of forced labour camps designed for the 're-education' of ideological opponents. ${ }^{48}$ Objective provisions limiting individual and collective religious freedom were abrogated immediately after the fall of the socialist regime. ${ }^{49}$ Since then, legislators have carefully considered the interests and needs of believers and churches/religious societies. ${ }^{50}$

From the ius vigens point of view, the current Criminal Code of the Slovak Republic contains only one provision concerning religious freedom, specifically the subject matter of the 'Restriction of the Freedom of Religion'. ${ }^{51}$ A special category of crime covers offences motivated by a negative attitude towards religious faith. These crimes (e.g. blackmail, murder, or bodily harm) are punished more severely if they are committed to incite violence or hatred against a group of people due to their religious faith. ${ }^{52}$ The crime of restricting freedom of religion is paradoxically not new. ${ }^{53}$ It falls under the category of 'crimes against freedom', and its class object is conceived in the widest possible sense. The law protects the right to religious faith as an absolute subjective right not subject to any legal restrictions, the right to be irreligious, ${ }^{54}$ the right to manifest religious faith externally and publicly, the right to change religious faith, and the right to choose a clerical or religious life. Criminal acts include forcing another to participate in a religious act, ${ }^{55}$ restraining another from participating in a religious act, and restraining another from

45 | Cf. Valeš, 2008, p. 143.

46 In the hands of the socialist regime, this was the perfect tool to use against clergy. The required conditions for its acquisition were citizenship, reliability, probity, and a vow of fidelity to the republic; see also Loužek, 2004, p. 40.

47 | Cf. § 207 zákona č. 86/1950 Sb., Trestný zákon; § 211 zákona č. 140/1961 Sb., Trestný zákon; § 7 zákona č. 265/1949 Sb. o rodinnom práve; § 10 zákona č. 94/1963 Sb. o rodine and § 20 zákona č. 97/1963 Sb. o medzinárodnom práve súkromnom a procesnom.

48 | Cf. zákon č. 247/1948 Sb. o táboroch nútenej práce. A large number of so-called 'politically unreliable' persons was also forced to work from 1950 to 1954 in so-called 'technical auxiliary battalions' (PTP); see also Balík, Hanuš, 2007, p. 103n.

49 | Cf. zákon č. 159/1989 Sb; see also Chenaux, 2012, p. 156n.

50 | Cf. §§ 101, 178 and 207 zákona č. 140/1961 Sb., Trestný zákon a zákon č. 159/1989 Sb.

51 | Cf. $\$ 193$ zákona č. 300/2005 Z. z., Trestný zákon.

52 | Cf. §§ 140, 189, ods. 2, písm. c); 145, ods. 1, písm. d) and 155, ods. 2, písm. c) zákona č. 300/2005 Z. z., Trestný zákon.

53 | This crime could be found in the Criminal Code No.140/1961 Sb., although the ability to claim for the protection of religion was restricted by the provisions of other laws, especially Law No. 218/1949 Sb. on the Economic Assurance of Churches and Religious Societies by the State and the Constitution, since its Article 24, Section 3 required education to be founded on a scientific worldview and close connection with the lives and work of the people. Moreover, § 101 of the Criminal Code sanctioned clergy abuse of their religious function; see also Casaroli, 2001, p. 209n.

54 | Cf. čl. 24, ods. 1 ústavného zákona č. 460/1992 Zb., Ústava Slovenskej republiky.

55 | The term 'religious act' means any act or ceremony relating to the profession of faith of any church or religious society, such as divine worship, the administering of sacraments, or the teaching of religion. 'Coercing' means using corporeal or mental violence, threats of violence or of other heavy loss; cf. Čentéš, 2013, p. 351. 
some other exercise of freedom of religion. ${ }^{56}$ A qualified subject matter requires special gravity; a commission of the crime on a protected person, acting with special motive, or acting in public. ${ }^{57} \mathrm{~A}$ crime that falls under fundamental subject matter is punishable by imprisonment for up to two years; a crime that falls under qualified subject matter is punishable by imprisonment for up to six years. ${ }^{58}$

Religious freedom is also protected by sanctioning crimes motivated by religious hatred or intolerance. This includes genocide, inhumanity and crimes of extremism consisting in foundation, support or propagation of a movement that causes the suppression of fundamental rights and freedoms or demonstration of sympathy with it; the vituperation of a nation, race or conviction; and the incitement to national, race, and ethnic hatred or apartheid..$^{59}$ These laws are meant to foster the peaceful existence of religious communities and their members, as well as their biological reproduction, identities, and lives. ${ }^{60}$ The seriousness of the crimes is reflected in the strong penal sanctions against them. Special provisions include the disculpating rules of $\S 340$ section 3 of the Criminal Code (misprision) and $\S 341$ section 4 of the Criminal Code (non-foiling of crime). ${ }^{61}$ Special subjects are under their authority exempt from criminal responsibility. For example, the clergy of registered churches and religious societies are exempt when meeting the provisions of the law would lead to the violation of the seal of confession. ${ }^{62}$ Here, the state recognizes the duty of silence on the part of those delegated to perform spiritual activities by churches and religious societies in accordance with their regulations. ${ }^{63}$ According to $\S$ 340 section 3 of the Criminal Code, someone who does not inform competent bodies of a crime punishable by a penal sanction of a minimum of 10 years or a crime of corruption is not criminally liable if it would lead to a violation of the seal of confession or compromise the information entrusted to the person orally or in writing under the understanding that the person was providing pastoral care. Analogously, a person is not culpable of the non-foiling of crime under $\S 341$ section 4 if meeting this duty would violate the seal of confession. The Criminal Code also protects the right of a witness to refuse to testify if

56 | Under 'other obstruction', we understand a violation that leads to the destruction of items used in religious ceremonies; cf. Čentéš, 2018, p. 391.

57 | A 'special motive' is an intention to incite violence or hatred against an individual or group of people for their religious faith; cf. §193, ods. 2 zákona č. 300/2005 Z. z., Trestný zákon.

58 | Cf. § 193 zákona č. 300/2005 Z. z., Trestný zákon.

59 | In criminal law, 'religious faith' means an active or passive relation to the given religion as a general theory, as well as to the worldview presented by any church or religious society; see also Čentéš, 2020, pp. 908-911, 941-945, 953-963.

60 | Cf. $\S \S 130,140 a, 418,421-424,424$ a and 425 zákona č. 300/2005 Z. z., Trestný zákon.

61 | See also Čeplíková, 2011, pp. 170-171.

62 | Cf. čl. 8 Základnej zmluvy medzi Slovenskou republikou a Svätou Stolicou vyhlásenej pod číslom 326/2001 Z. z. ako oznámenie Ministerstva zahraničných vecí and čl. 8 Dohody medzi Slovenskou republikou a registrovanými cirkvami a náboženskými spoločnostami publikovanej pod č. 250/2002 Z. z. This may be explained by the fact that whoever receives information from a confessing person or some other person making a legitimate disclosure has a right not to share it with the state, even when there is a legal duty to do so. Slovak laws also guarantee the inviolability of secret information orally or in written form entrusted to a person carrying out pastoral care; cf. Šmid, Vasil', 2001, pp. 460-461. Not surprisingly, the socialist regime did not accept the right of clergy to refuse to testify on matters protected by confessional secrets. In several cases, they even tried to pierce into this intimate sphere and utilize such information against political opponents; cf. Hrdina, 2004, pp. 166-167, 223n.

63 | Cf. čl. 24, ods. 1 ústavného zákona č. 460/1992 Zb., Ústava Slovenskej republiky. 
doing so would violate the seal of confession or compromise the information entrusted to the person orally or in writing under the understanding that the person was providing pastoral care. ${ }^{64}$

In a broader context, there are state religion laws regulating the competences of registered churches and religious societies in the area of penitentiary care. According to $\S 4$ of the Code of Criminal Procedure, bodies acting in criminal proceedings may cooperate to produce an educational effect during a criminal procedure or prevent criminal activities; the scope of this law includes special-interest associations, such as registered churches and religious societies..$^{65}$ This is reflected in agreements with churches and religious societies to provide spiritual and pastoral care to prisoners. Such organisations have the right to access places of detention and imprisonment, ${ }^{66}$ and convicted persons have the right to possess spiritual and religious literature ${ }^{67}$ Slovak law concerning prisoners in collusive detention is paradoxically more severe, even though such prisoners should be considered innocent according to the principle of the presumption of innocence. An accused in collusive detention may be provided with pastoral care only with the consent of a competent body acting in criminal proceedings or a court, or if spiritual or pastoral care is not being provided by penitentiary clergy that keeps the individual register about it. ${ }^{68}$ The activities of churches and religious societies in these institutions most frequently take the form of worship, confessions, conversations, pastoral visits connected with spiritual care, spiritual services, providing and explaining religious literature, offering lectures or concerts, guiding study groups, and assisting in the resocialization of prisoners to prepare them for life after release. ${ }^{69}$ Whereas clergy have to respect the rules regulating the execution of punishment and the constitutional order of the institution, its representatives are obliged to provide clergy with a suitable space for their activities. ${ }^{70}$

64 | Cf. §130, ods. 2 zákona č. 301/2005 Z. z., Trestný poriadok. An analogous regulation granting the right to refuse to provide information to Slovak Republic police is intended for those for whom this would violate confessional secrets or confidential information entrusted to them as people carrying out pastoral care; cf. § 17, ods. 4 zákona č. 171/1993 Z. z. o Policajnom zbore Slovenskej republiky. 65 | These may, for example, offer a guarantee for the correction of an accused person; a guarantee to complete the correction of the person and ask for his or her parole; or a conditional suspension of the punishment; eventually, they will propose that the detention be replaced by their guarantee and ask for a petition of pardon; cf. Čeplíková, 2008, p. 23; Čentéš, 2019, p. 16.

66 | After all, this opportunity assumes the fundamental regulation of state religious law, which is Law No. 308/1991 Zb. on Freedom of Religious Belief and the Status of Churches and Religious Societies; cf. § 9 zákona č. 308/1991 Zb. o slobode náboženskej viery a postavení cirkví a náboženských spoločností. Their participation in the correction of convicted persons is regulated in more detail in other regulations; cf. § 68 vyhlášky č. 368/2008 Z. z., Poriadok výkonu trestu and § 44 zákona č. 221/2006 Z. z. o výkone väzby.

67 | Cf. Čeplíková, 2011, p. 173.

68 | Cf. čl.7Zmluvy medzi Slovenskou republikou a Svätou stolicou o duchovnej službe v ozbrojených silách a zboroch publikovaná pod č. 648/2002 Z. z. and čl. 8 Dohody medzi Slovenskou republikou a registrovanými cirkvami a náboženskými spoločnostami o výkone pastoračnej služby ich veriacim v ozbrojených silách a ozbrojených zboroch Slovenskej republiky publikovaná pod č. 270/2005 Z. z. 69 | Cf. § 17 vyhlášky č. 368/2008 Z. z., Poriadok výkonu trestu and § 44 zákona č. 221/2006 Z. z. o výkone väzby.

70 | According to canon law, Catholics in detention or imprisonment in Slovakia fall under the jurisdiction of the armed forces of the Slovak Republic. Regular spiritual care is provided to them by military chaplains; cf. čl.1-3 Zmluvy medzi Slovenskou republikou a Svätou stolicou o duchovnej službe v ozbrojených silách a zboroch publikovanej pod č. 648/2002 Z.z. ako oznámenie ministerstva zahraničných vecí Slovenskej republiky. 
Elements of state religious law, such as article 12 section 2 of the Constitution of the Slovak Republic, are to be found in the Criminal Code's protection of foreign perpetrators of criminal acts; banishment abroad is not permitted if this would endanger the offender's freedom or life, or if it is based on religious membership. ${ }^{71}$ Procedurally, anyone facing banishment abroad can present evidence of potential persecution because of their religion. ${ }^{72}$ The question of sects is connected to both the state religious law and criminal law. Although Slovak law does not recognize the term 'sect', state bodies use either the sociological definition applied by the Ministry of Culture or the definition elaborated by the Department of Home Affairs of the Slovak Republic, ${ }^{73}$ which describes a sect as a destructive religious group based on fanaticism produced by a deceptive founder that hinders moral development (particularly that of youth), violates law and order, or with their ideology and opinions endangers life, health, or property and violates public statutes. This crime can be committed only by a natural person, not a corporate entity, and thus may not be committed directly by a sect or religious society. The fact that this crime was committed by the member of a sect would thus have only informational value for the internal needs of Slovakian police monitoring their activities in order to assess their negative impacts on members and on society as a whole. ${ }^{74}$

\section{Conclusion}

Churches and religious societies traditionally perform important social tasks that manifest also in family and criminal law. The state accepts religion's role in strengthening the family, seeing it as the fundamental cell of society. ${ }^{75}$ Most churches and religious societies in Slovakia follow the same goal, following, for example, the Biblical principle about the indissolubility of marriage, which produces families. In Europe, the obligatory civil form of the marriage contract was retained only by countries in the NapoleonicBismarck tradition, to which Slovakia does not belong. Slovakia's high degree of religiosity and longstanding excellent experiences with churches and religious societies, which exclude any historical anticlericalism, suggest that alternative forms of the marriage contract will be preserved..$^{76} \mathrm{~A}$ marriage thus may be contracted before the representative of the state or that of a registered church or religious society; this may be considered one of the most fundamental signs of Slovakia's full respect for freedom of conscience and religion. References of state law to the law of individual churches and religious societies may be perceived as a demonstration of respect for their right to administer their own matters freely and independently. ${ }^{77}$ The ideal de lege ferenda proposal improving state

71 | Cf. § 65, ods. 2, písm. e) and f) zákona č. 300/2005 Z. z., Trestný zákon.

72 | Cf. §§ 501 and 510, písm. b) zákona č. 301/2005 Z. z., Trestný poriadok; see also Čentéš, 2019, pp. 939, 950.

73 | The Department of Home Affairs monitors extremist groups, and sects are considered religiously oriented extremists; see also Nemec, 1997, p. 21; Čikeš, 2010, p.12-13.

74 | Cf. Nariadenie Ministerstva vnútra SR č. 45/2004 o postupe v oblasti boja s extrémizmom a o zriadení monitorovacieho strediska rasizmu a xenofóbie.

75 | Cf. čl. 2 zákona č. 36/2005 Z. z. o rodine.

76 | Cf. Tretera, 2002, pp. 16, 146-147.

77 | Cf. čl. 16, ods. 2 ústavného zákona č. 23/1991 Zb., ktorým sa uvádza Listina základných práv a slobôd. 
religious law could consist in a full and automatic acceptance of the judgments on nullity of marriage handed down by Catholic courts and of judgments on the dissolution or separation of marriage given by Church authorities. ${ }^{78}$ The decisions of Church courts are more important to believers than are the decisions of secular courts. Moreover, parties who apply to a Church court for nullity are not interested in validating their marriage using the convalidatio simplex or sanatio in radice. ${ }^{79}$ It is thus redundant to force believers to undergo the same procedure before the state court, which evokes the socialist era, when a church marriage could be conducted only after the marriage had been contracted before a state body. Concerning criminal law, its substantial law portion contains rules protecting the interests of individuals, churches, and religious societies (i.e. personal and collective religious freedom). The provisions of criminal procedural law help churches and religious societies perform the important task of taking care of prisoners, while protecting the confidentiality rights of those who provide spiritual care.

78 | Cf. čl. 10, ods. 2 Základnej zmluvy medzi Slovenskou republikou a Svätou Stolicou vyhlásenej pod číslom 326/2001 Z. z. ako oznámenie Ministerstva zahraničných vecí. 


\section{Bibliography}

Balík, S., Hanuš, J. (2007) Katolická církevv Československu 1945-1989. Brno: Centrum pro studium demokracie a kultury.

Casaroli, A. (2001) Trýzeň trpělivosti. Svatý stolec a komunistické země (1963-1989). Kostelní Vydří: Karmelitánské nakladatelství.

| Dolinský, J. (1996) Dejiny Cirkvi. Prvý diel. Krest'anskýstarovek. Bratislava: Dobrá kniha.

| Čentéš, J. (2019) a kol.: Trestný poriadok. Vel'ký komentár. Žilina: Eurokódex.

| Čentéš, J. (2013) a kol.: Trestný zákon. Vel'kýkomentár. Žilina: Eurokódex.

| Čentéš, J. (2018) a kol.: Trestný zákon. Vel'ký komentár. Žilina: Eurokódex.

| Čentéš, J. (2020) a kol.: Trestný zákon. Vel'ký komentár. Žilina: Eurokódex.

Čeplíková, M. (2008) 'Súčasný stav konfesného práva v Slovenskej republike' in Grešková, L. (ed.) Vzt'ahy štátu a cirkví v Európe: Súčasné otázky a trendy na začiatku 21. storočia. Zborník z rovnomennej medzinárodnej konferencie, ktorú usporiadal Ústav pre vzt'ahy štátu a cirkví v Bratislave v dňoch 8. - 10. novembra 2007. Bratislava: Ústav pre vztahy štátu a cirkví, Bratislava.

Čeplíková, M. (2011) Konfesné právo v Slovenskej republike. Vybrané kapitoly z histórie a súčasnost'. Bratislava: Ústav pre vzt'ahy štátu a cirkví.

Čikeš, R. (2010) Vzt'ahy štátu a cirkví na Slovensku. Bratislava: Ústav pre vztahy štátu a cirkví.

Fiala, P., Hanuš, J. (2001) Katolická církev a totalitarismus v českých zemích. Brno: Centrum pro studium demokracie a kultury.

| Fischerová, J. (1992) ‘Uzatváranie manželstva’, Verejná správa. Roč. 47, č. 20.

Grešková, L. (ed.) (2008) Vzt'ahy štátu a cirkví v Európe: Súčasné otázky a trendy na začiatku 21. storočia. Zborník z rovnomennej medzinárodnej konferencie, ktorú usporiadal Ústav pre vztahy štátu a cirkví v Bratislave v dňoch 8.-10. novembra 2007. Bratislava: Ústav pre vzt'ahy štátu a cirkví.

Hrdina, I. A. (1996) ‘Kanonické uzavření manželství v českém právním řádu', Právník. Č. 5. Hrdina, A. (2004) Náboženská svoboda v právu České republiky. Praha: Eurolex Bohemia.

Chenaux, P. (2012) Katolická církev a komunismus v Evropě (1917-1989). Od Lenina kJanu Pavlu II. Praha: Rybka Publishers.

| Kizlink, K. (1969) ‘Právo Vel'kej Moravy’, Právnické štúdie. Roč. 17, Č. 3.

I Kumor, B. (2001) Cirkevné dejiny 2. Raný krest'anský stredovek. Levoča: Polypress.

Kumor, B., Dlugoš, F. (2003) Cirkevné dejiny 6. Novovek. Obdobie absolutizmu a osvietenstva. Levoča: Nadácia Kňazského seminára biskupa Jána Vojtaššáka. 
Kumor, B. (2003) Cirkevné dejiny 7. Novovek, 1815-1914, Levoča: Nadácia Kňazského seminára biskupa Jána Vojtaššáka.

Kumor, B., Dlugoš, F. (2004) Cirkevné dejiny 8. Súčasné obdobie, 1914-2000. Levoča: Nadácia Kňazského seminára biskupa Jána Vojtaššáka.

Laclavíková, M., Vladár, V. (2017) ‘Rímsko-kánonické reflexie inštitútu zasnúbenia v uhorskom, československom a slovenskom práve', Studia theologica. Roč 19, č. 4.

Loužek, M. (2004) 'Církvím prospěje konkurence', in Loužek, M. (ed.) Vztáah církví a státu. Praha: Centrum pro ekonomiku a politiku.

Madleňáková, L. (2010) Výhrada svědomí jako součást svobody myšlení, svědomí a náboženského vyznání. Praha: Linde.

| Malý, R. (2001) Církevní dějiny. Olomouc: Matice cyrilometodějská.

| Markschies, C. (2005) Mezi dvěma světy. Dějiny antického křest'anství. Praha: Vyšehrad. Nemec, M. (1997) Vybrané kapitoly z cirkevného práva. Bratislava: Manz a Právnická fakulta Univerzity Komenského v Bratislave.

Pokorný, L. (1987) ‘Staroslověnské kající řády a penitenciály’, in Pokorný, L. (eds.) Odkaz soluňských bratří. Sborník k 1100. výročí úmrtí sv. Metoděje. Praha: Česká katolická Charita.

Samsour, J. (1907) Církevní dějiny obecné, Praha: Cyrillo-Methodějská knihtiskárna a Nakladatelství V. Kotrba.

Šmid, M., Vasil', C. (2001) 'Základná zmluva medzi Slovenskou republikou a Svätou stolicou: nedotnutel'nost' spovedného alebo zvereného tajomstva', Justičná revue. Roč. 53, č. 4.

Tretera, J. R. (2002) Stát a církve v České republice. Kostelní Vydří: Karmelitánské nakladatelství.

| Valeš, V. (2008) Konfesní právo. Průvodce studiem. Plzeň: Aleš Čeněk.

| Vašica, J. (1996) Literární památky epochy velkomoravské. Praha: Vyšehrad, 1996.

Weir, T. (2014) Secularism and Religion in Nineteenth-Century Germany: The Rise of the Fourth Confession. Cambridge: Cambridge University Press.

\section{| Legal sources}

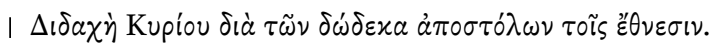

| Responsa Nicolai ad consulta Bulgarorum.

| Zákon č. 320/1919 Sb. z. a n., vykonávacie nariadenie č. 362/1919 Sb. z. a n.

| Zákon č. 113/1924 Sb. z.a n.

| Zákon č. 247/1948 Sb. o táboroch nútenej práce. 
| Zákon č. 265/1949 Sb. o rodinnom práve.

| Zákon č. 86/1950 Sb., Trestný zákon.

| Zákon č. 68/1957 Zb. o umelom prerušení tehotenstva.

| Zákon č. 140/1961 Sb., Trestný zákon.

| Zákon č. 94/1963 Sb. o rodine.

| Zákon č. 97/1963 Sb. o mezinárodnom práve súkromnom a procesnom.

Codex Iuris Canonici - Kódex Kánonického Práva. Latinsko-slovenské vydanie. Bratislava : Spolok sv. Vojtecha, 1996.

| Zákon č. 73/1986 Zb. o umelom prerušení tehotenstva.

| Zákon č. 159/1989 Sb.

| Ústavný zákon č. 23/1991 Zb., ktorým sa uvádza Listina základných práv a slobôd.

Zákon č. 308/1991 Zb. o slobode náboženskej viery a postavení cirkví a náboženských spoločností.

| Zákon č. 234/1992 Sb.

| Ústavný zákon č. 460/1992 Zb., Ústava Slovenskej republiky.

| Zákon č. 171/1993 Z. z. o Policajnom zbore Slovenskej republiky.

| Zákon č. 154/1994 Z.z. o matrikách.

| Vyhláškač. 302/1994Z.z.

Základná zmluva medzi Slovenskou republikou a Svätou Stolicou vyhlásená pod číslom 326/2001Z. z. ako oznámenie Ministerstva zahraničných vecí.

Dohoda medzi Slovenskou republikou a registrovanými cirkvami a náboženskými spoločnost'ami publikovaná pod č. 250/2002 Z.z.

Nariadenie Ministerstva vnútra SR č. 45/2004 o postupe v oblasti boja s extrémizmom a o zriadení monitorovacieho strediska rasizmu a xenofóbie.

| Zákon č. 36/2005 Z. z. o rodine.

| Zákon č. 300/2005 Z. z., Trestný zákon.

| Zákon č. 301/2005 Z. z., Trestný poriadok.

| Zákon č. 221/2006 Z. z. o výkone väzby.

| Vyhláška č. 368/2008 Z. z., Poriadok výkonu trestu. 